\title{
HIV-associated tuberculosis: relationship between disease severity and the sensitivity of new sputum-based and urine-based diagnostic assays
}

\author{
Stephen D Lawn ${ }^{1,2^{*}}$, Andrew D Kerkhoff ${ }^{1,3}$, Monica Vogt ${ }^{1}$ and Robin Wood ${ }^{1}$
}

\begin{abstract}
Background: Reducing mortality from HIV-associated tuberculosis (TB) requires diagnostic tools that are rapid and have high sensitivity among patients with poor prognosis. We determined the relationship between disease severity and the sensitivity of new sputum-based and urine-based diagnostic assays.

Methods: Consecutive ambulatory patients enrolling for antiretroviral treatment in South Africa were screened for TB regardless of symptoms using diagnostic assays prospectively applied to sputum (fluorescence smear microscopy, Xpert MTB/RIF and liquid culture (reference standard)) and retrospectively applied to stored urine samples (Determine TB-LAM and Xpert MTB/RIF). Assay sensitivities were calculated stratified according to pre-defined indices of disease severity: CD4 count, symptom intensity, serum C-reactive protein (CRP), hemoglobin concentration and vital status at 90 days.

Results: Sputum culture-positive TB was diagnosed in 15\% (89/602) of patients screened and data from 86 patients were analyzed (median CD4 count, 131 cells/ $\mu \mathrm{L}$ ) including 6 (7\%) who died. The sensitivity of sputum microscopy was $26.7 \%$ overall and varied relatively little with disease severity. In marked contrast, the sensitivities of urine-based and sputum-based diagnosis using Determine TB-LAM and Xpert MTB/RIF assays were substantially greater in sub-groups with poorer prognosis. Rapid diagnosis from sputum and/or urine samples was possible in $>80 \%$ of patients in sub-groups with poor prognosis as defined by either CD4 counts $<100$ cells/ $/ \mathrm{L}$, advanced symptoms, CRP concentrations $>200 \mathrm{mg} / \mathrm{L}$ or hemoglobin $<8.0 \mathrm{~g} / \mathrm{dl}$. Retrospective testing of urine samples with Determine TB-LAM correctly identified all those with TB who died.

Conclusions: The sensitivities of Xpert MTB/RIF and Determine TB-LAM for HIV-associated TB were highest among HIV-infected patients with the most advanced disease and poorest prognostic characteristics. These data provide strong justification for large-scale intervention studies that assess the impact on survival of screening using these new sputum-based and urine-based diagnostic approaches.
\end{abstract}

Keywords: Tuberculosis, HIV, Diagnosis, Mortality, Africa, Screening, Xpert, Lipoarabinomannan, Urine

\section{Background}

Tuberculosis (TB) remains the leading cause of HIVrelated mortality worldwide, accounting for approximately one quarter of HIV/AIDS deaths [1]. A majority of these

\footnotetext{
* Correspondence: stephen.lawn@lshtm.ac.uk

${ }^{1}$ The Desmond Tutu HIV Centre, Institute for Infectious Disease and Molecular Medicine, Faculty of Health Sciences, University of Cape Town, Cape Town, South Africa

2Department of Clinical Research, Faculty of Infectious and Tropical Diseases, London School of Hygiene and Tropical Medicine, Keppel Street, London WC1E 7HT, UK

Full list of author information is available at the end of the article
}

deaths occur in sub-Sahara Africa, which bears $79 \%$ of the global burden of HIV-associated TB [1]. Very high frequencies of undiagnosed disseminated TB have been reported in post-mortem studies of people dying with HIV/AIDS in sub-Saharan Africa both before and during the scale-up of antiretroviral treatment (ART) [2-5]. These data suggest that the true contribution of TB to HIV-related deaths may be underestimated and that failure of ante-mortem diagnosis is a major problem [6].

A number of factors undermine TB diagnosis in people with advanced HIV-related immunodeficiency $[7,8]$. The

\section{Biomed Central}


clinical presentation is often non-specific, with only a minority of patients with proven pulmonary disease reporting chronic cough of more than two weeks duration $[9,10]$. Extrapulmonary and disseminated forms of the disease are common and difficult to diagnose $[7,8]$. In resource-limited settings, heavy reliance is still placed on outdated TB diagnostic tests, such as sputum smear microscopy and chest radiography, both of which have limited diagnostic accuracy in those with advanced immunodeficiency $[7,11]$. Where culture is available, diagnosis may take several weeks. Thus, TB diagnoses are often either delayed or missed in those with poor immune function and high risk of death.

Over the past few years, considerable progress has been made in the development of new, rapid assays for TB that have useful diagnostic accuracy in patients living with HIV [11-13]. These assays include the Xpert MTB/ RIF (Cepheid Inc., Sunnyvale, CA, USA) rapid molecular assay, which can be applied to both respiratory and non-respiratory samples [11]. In addition, the Determine TB-LAM assay (Alere Inc., Waltham, MA, USA) is a simple lateral-flow (strip-test) that detects lipoarabinomannan (LAM) in urine [13]. We have previously reported on the useful diagnostic accuracy of these two assays during active screening of patients prior to starting ART in a South African township [13-15]. However, for new assays to reduce deaths from HIV-associated TB, they must have adequate sensitivity among patients with poor prognosis and highest risk of death. In the present analysis, we therefore ascertained how the sensitivities of urine- and sputumbased approaches to diagnosis using the Xpert MTB/RIF and Determine TB-LAM assays varied according to disease severity as reflected by CD4 cell count, symptom intensity, C-reactive protein (CRP) concentration, hemoglobin concentration and vital status at 90 days of follow-up.

\section{Methods}

The ART services in Gugulethu Township in Cape Town with its high burden of TB and mortality have all previously been described in detail [16-19]. Between 12 March 2010 and 20 April 2011, consecutive patients newly referred to start ART and who were aged $>18$ years, ART-naive and had no current TB diagnosis were consecutively recruited regardless of symptoms as previously described [13]. All participants provided written informed consent and the study was approved by the research ethics committees of the University of Cape Town, South Africa, and the London School of Hygiene \& Tropical Medicine, UK.

Patients were clinically characterized, routine baseline investigations were done and then they were screened for TB. The standardized symptom-screening questionnaire included the World Health Organization (WHO) symptom screen (the presence of more than one of the following symptoms: cough, fever, weight loss or night sweats [9]).
Two sputum samples were requested from each patient; a spot specimen was followed by a second that was induced using nebulized 3\% hypertonic saline. If necessary, both specimens were induced. Urine samples were collected and stored at $-20^{\circ} \mathrm{C}$. Blood CD4 cell counts and plasma viral load were measured on all patients via the routine laboratory services. Chest radiographs were obtained and reported by an experienced reader certified in the use of the chest radiograph reading and recording system $[20,21]$.

\section{Laboratory procedures}

Sputum specimens were processed using standardized protocols and external quality assurance procedures by a centralized accredited laboratory as previously described [13]. Samples were decontaminated with N-acetyl-Lcysteine and sodium hydroxide and concentrated by centrifugation. Smears prepared from the sputum pellets were stained with auramine $\mathrm{O}$ fluorescent stain for fluorescence microscopy and equal volumes of the remaining pellet were tested by liquid culture and the Xpert MTB/RIF assay. All smears graded as scanty, 1+, $2+$ and $3+$ were defined as 'smear-positive'. Cultures were performed using Mycobacterial Growth Indicator Tubes (MGIT, Becton Dickinson, Sparks, MD, USA) and were incubated for up to six weeks. Cultures positive for acid-fast bacilli were identified as Mycobacterium tuberculosis complex using the MTBDRplus assay (Hain Lifesciences, Nehren, Germany). Xpert MTB/RIF assays were done according to the manufacturer's instructions. The results of all tests were read by technologists blinded to the outcomes of the other assays.

Frozen urine samples were defrosted and retrospectively analyzed for the presence of lipoarabinomannan (LAM) using the commercially available Determine TB-LAM lateral-flow assay. Positive results were recorded when the test band had equal or greater intensity to the weakest band on the reference card. Defrosted urine samples $(2.0 \mathrm{~mL})$ were also concentrated by centrifugation, resuspended in $0.75 \mathrm{~mL}$ of phosphate buffer and tested retrospectively using the Xpert MTB/RIF assay.

Concentrations of CRP were measured in duplicate serum samples using the Quantikine enzyme-linked immunosorbent assay (R\&D Systems Inc., Minneapolis, MN, USA) according to the manufacturer's instructions.

\section{Patient outcomes}

Patients were followed up within the routine ART service and patients diagnosed as having TB were referred to treatment clinics within the township. The time to initiation of TB treatment was ascertained and ART service patient records were reviewed to determine vital status at three months. 


\section{Definitions and analysis}

Patients were defined as having TB if M. tuberculosis was cultured from one or more sputum samples. TB patients were then categorized according to $\mathrm{CD} 4$ cell count ( $>200,101$ to 200 and $<200$ cells/ $\mu \mathrm{L}$ ), symptom profile, serum CRP concentration (using strata approximating to quartiles), hemoglobin concentration (using strata corresponding to the WHO classification of anemia [22]) and vital status after three months follow-up, providing stratification by disease severity. Patients were characterized using simple descriptive statistics. The sensitivity of the Xpert MTB/RIF and Determine TB-LAM assays were then calculated for patient groups stratified by the pre-defined indices of disease severity and using culture as the reference standard. Assay sensitivities across these strata were compared using the chi-square and Fisher's exact tests as appropriate. All statistical tests were two-sided at alpha $=0.05$.

\section{Results}

\section{Patients and TB diagnoses}

Of 604 consecutive patients who fulfilled eligibility criteria, 602 agreed to participate. Sputum samples could be obtained from 542 (90.0\%) patients. Smear microscopy, culture and Xpert MTB/RIF results were available from one or more sputum samples from 523 patients (Figure 1). Of 89 patients diagnosed with sputum culture-positive TB, data permitting stratification by disease severity were available for 86. Of these, additional data on urine-based diagnostics were available for 81 patients.
Patients with TB $(\mathrm{n}=86)$ had a median age of 33.1 years (IQR, 28.3 to 39.9) and 64\% were female. The median CD4 cell count was 131 cells $/ \mu \mathrm{L}$ (IQR, 52 to 204) and $47.7 \%$ had WHO stage 3 or 4 disease prior to TB screening. The median hemoglobin was $10.8 \mathrm{~g} / \mathrm{dL}$ (IQR, 8.8 to 12.0 ) and the median CRP concentration was $57.8 \mathrm{mg} / \mathrm{L}$ (IQR, 20.3 to 202.7; range, 1.7 to 560 ). Symptom severity was classified into three mutually exclusive groups: those with a negative WHO symptom screen $(n=15)$, those with a positive WHO symptom screen but without cough of two or more weeks' duration $(n=49)$ and those with a positive WHO symptom screen including a cough of two or more weeks' duration $(\mathrm{n}=22)$.

Among the culture-confirmed cases of TB $(n=86)$, the time to positivity in liquid culture was prolonged (median, 16 days; IQR, 11 to 21). Among 83 patients with evaluable chest radiographs, any radiological abnormality was observed in 61 (73.5\%), central abnormalities (mediastinal and hilar lymphadenopathy) were observed in 23 (27.7\%), parenchymal abnormalities in 57 (66.3\%) and pleural abnormalities in 17 (20.5\%). The median number of radiographic zones involved with parenchymal abnormalities was two out of six (IQR, 0 to 4 ) but was greater in the sub-set of patients with prolonged cough (median, four zones; IQR, 2 to 5).

\section{Indices of disease severity}

Patients with TB $(n=86)$ were next stratified using four different indices of disease severity: CD4 cell count

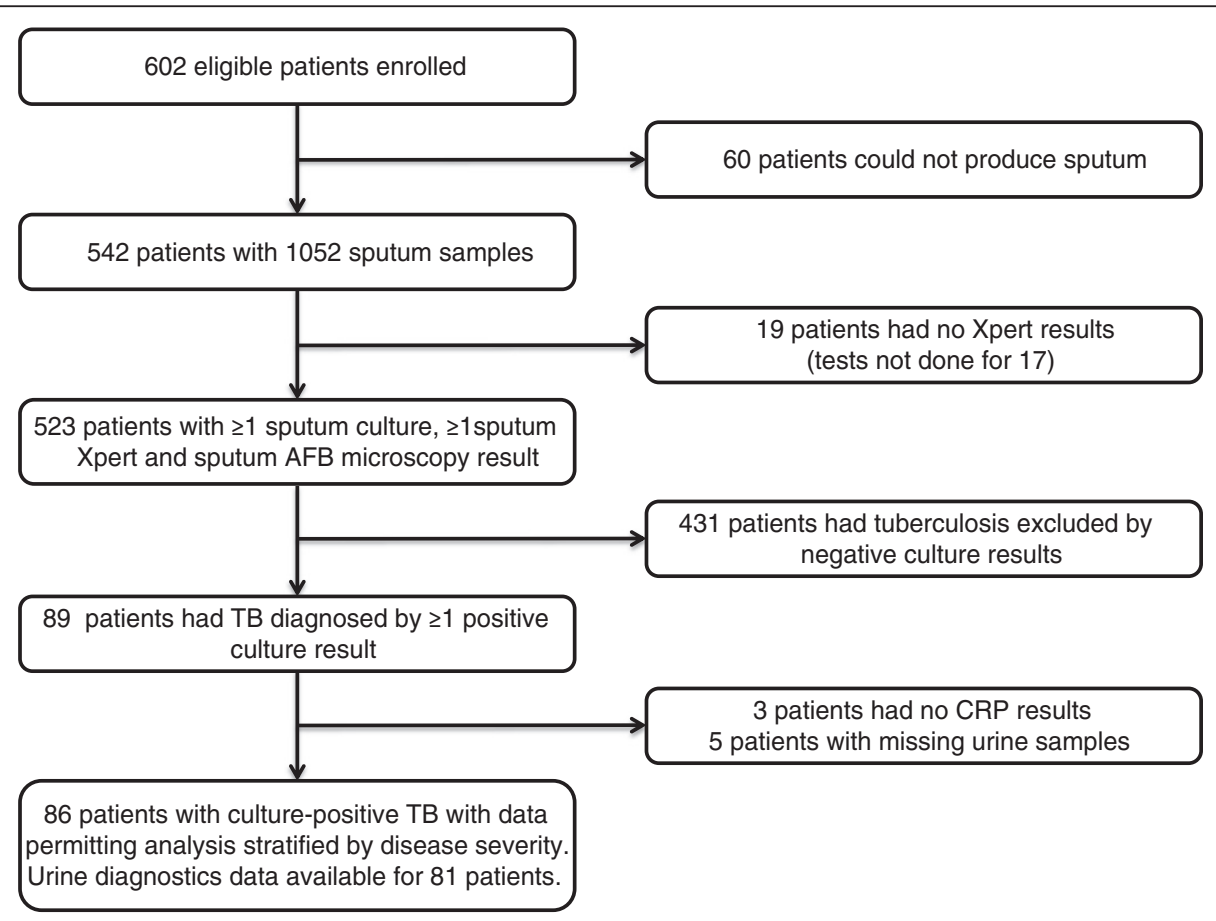

Figure 1 Flow diagram showing the numbers of patients studied. 
$(<100,100$ to 200 and $>200$ cells $/ \mu \mathrm{L})$, increasing symptom severity (as defined above), CRP concentration $(<20,20$ to 60,61 to 200 and $>200 \mathrm{mg} / \mathrm{L})$ and hemoglobin concentration $(<8,8$ to 11 and $>11 \mathrm{~g} / \mathrm{dL})$. Table 1 shows the characteristics of these groups of patients stratified by these indices and confirms that patients in poorer prognostic groups had other adverse characteristics. In contrast, when patients were grouped according to the presence or absence of chest radiographic abnormalities, it was clear that radiographic appearances in this patient group did not provide a useful index of disease severity (data not shown).

\section{Sensitivity of TB diagnostics and disease severity}

The diagnostic sensitivities of the various sputum-based and urine-based assays differed substantially. The overall sensitivities ranked in descending order were $70.9 \%(95 \%$ CI, 60.1 to 80.2 ), $58.1 \%$ (95\% CI, 47.0 to 68.7 ), $29.6 \%$ (95\% CI, 20.0 to 40.8 ), $26.7 \%$ (95\% CI, 17.8 to 37.4 ) and $18.5 \%$ (95\% CI, 10.8 to 28.7 ) when using Xpert MTB/RIF (two sputum samples), Xpert MTB/RIF (one sputum sample), sputum smear microscopy, Determine TB-LAM (urine) and Xpert MTB/RIF (urine), respectively. However, the sensitivities of these assays varied substantially according to disease severity (Figure 2).

The predominant pattern that emerged from these analyses was that the sensitivities of both urine-based and sputum-based assays tended to be higher among those with lower CD4 cell counts (Figure 2a), more advanced symptoms (Figure $2 \mathrm{~b}$ ), higher CRP concentrations (Figure 2c) and lower hemoglobin concentrations (Figure 2d). These data indicate that rapid diagnosis from sputum and/or urine samples using Xpert MTB/RIF and/or Determine TB-LAM was possible in $>80 \%$ of patients categorized in the four groups with worst prognosis (CD4 count $<100$ cells $/ \mu \mathrm{L}$, advanced symptoms, $\mathrm{CRP} \geq 200 \mathrm{mg} / \mathrm{L}$ and hemoglobin $<8.0 \mathrm{~g} / \mathrm{dl}$ ).

The association between disease severity and diagnostic sensitivity was weakest for sputum smear microscopy for which there was no significant association with CD4 count (Figure 2a) or CRP concentration (Figure 2c). The sensitivity of smear microscopy did not exceed $50.0 \%$ in any of the patient sub-groups. In contrast, the sensitivity of Xpert MTB/RIF when testing either one or two sputum samples was substantially greater when comparing the most favorable and least favorable prognostic sub-groups for all of the four indices of disease severity. The median increments in sensitivity were $47.0 \%$ (range 27.7 to 50.6 ) when testing one sputum sample and $34.4 \%$ (range, 27.4 to 47.6 ) when testing two samples.

Although the overall sensitivity of Determine TB-LAM was low, the associations between the sensitivity of Determine TB-LAM point-of-care assay for urine lipoarabinomannan and disease severity were extremely striking
(Figure 2). In all of the least favorable prognostic categories, Determine TB-LAM detected a majority of cases, with sensitivity ranging from $51.7 \%$ to $100 \%$. When comparing the most favorable and least favorable prognostic categories for each of the four indices of disease severity, the median increment in sensitivity was $53.3 \%$ (range, 38.1 to 100.0 ).

The association between the sensitivity of Xpert MTB/ RIF when testing urine samples and disease severity was strong for each of the indices with the exception of symptom severity (Figure 2). In the least favorable prognostic categories, sensitivities ranged from $28.6 \%$ to $50.0 \%$. When comparing the most favorable and least favorable prognostic categories for each of the four indices of disease severity, the median increment in sensitivity was $33.9 \%$ (range, 7.2 to 43.9 ).

Vital status during follow-up and sensitivity of TB diagnostics We next assessed how the diagnostic sensitivity of the assays differed according to vital status at 90 days of follow-up (Figure 3). There was no significant association between the sensitivity of sputum tests (smear microscopy and Xpert MTB/RIF) and vital status, although the sensitivity of Xpert MTB/RIF tended to be higher among those who died. In contrast, despite limited statistical power, there was a very strong relationship between the sensitivity of urine-based tests and vital status at 90 days (Figure 3). The sensitivities of Determine TB-LAM and of Xpert MTB/RIF testing of urine were $75.0 \%$ and $65.5 \%$ higher, respectively, among patients who died compared to those who survived.

We next plotted Venn diagrams to reveal the relationship between the sensitivities of the different diagnostic approaches for culture-positive TB cases and for the subset who had died during 90 days of follow-up (Figure 4). In contrast to sputum smear microscopy, Xpert MTB/RIF testing of two sputum samples or testing of urine using Determine TB-LAM was able to diagnose TB among all those patients who subsequently died.

\section{Discussion}

Since the advent of the AIDS pandemic, the lack of rapid and accurate assays for HIV-associated TB in those with advanced immunodeficiency has been a major hindrance to reducing deaths from these diseases in resource-limited settings [6]. We found a very high prevalence of culturepositive TB, but diagnosis with conventional tests was challenging. Only one quarter of cases were sputum smearpositive, $26 \%$ had normal chest radiographs and the median time to culture positivity was 16 days. However, the key finding of this study was that compared to smear microscopy, the incremental diagnostic sensitivity provided by the Xpert MTB/RIF assay (applied to sputum or urine samples) and the Determine TB-LAM urine test were greatest among the patients with the worst prognostic characteristics: 
Table 1 Characteristics of patients $(n=86)$ with tuberculosis (TB) stratified by indices of disease severity and survival

\begin{tabular}{|c|c|c|c|c|c|c|c|c|c|c|c|c|c|c|}
\hline \multirow{2}{*}{\multicolumn{3}{|c|}{$\begin{array}{c}\text { Blood CD4 cell count } \\
\text { (cells } / \mu \mathrm{L} \text { ) }\end{array}$}} & \multirow{2}{*}{\multicolumn{3}{|c|}{ Symptom severity }} & \multirow{2}{*}{\multicolumn{4}{|c|}{$\begin{array}{l}\text { C-reactive protein } \\
\text { Concentration (mg/L) }\end{array}$}} & \multirow{2}{*}{\multicolumn{3}{|c|}{$\begin{array}{c}\text { Hemoglobin concentration } \\
(\mathrm{g} / \mathrm{dL})\end{array}$}} & \multirow{2}{*}{\multicolumn{2}{|c|}{$\begin{array}{l}\text { Vital status at } \\
90 \text { days }\end{array}$}} \\
\hline & & & & & & & & & & & & & & \\
\hline$>200$ & $\begin{array}{l}101 \text { to } \\
200\end{array}$ & 0 to 100 & $\begin{array}{c}\text { WHO } \\
\text { screen } \\
\text { negative }\end{array}$ & $\begin{array}{l}\text { WHO screen } \\
\text { positive }+ \\
\text { cough } \\
<2 \text { weeks }\end{array}$ & $\begin{array}{l}\text { WHO screen } \\
\text { positive }+ \\
\text { cough } \\
\geq 2 \text { weeks }\end{array}$ & $<20$ & 20 to 60 & $\begin{array}{l}61 \text { to } \\
200\end{array}$ & $>200$ & $>11.0$ & $\begin{array}{l}8.0 \text { to } \\
11.0\end{array}$ & $<8.0$ & $\begin{array}{l}\text { Alive at } \\
90 \text { days }\end{array}$ & $\begin{array}{l}\text { Death at } \\
90 \text { days }\end{array}$ \\
\hline$n=24)$ & $(n=28)$ & $(n=34)$ & $(n=15)$ & $(n=49)$ & $(n=22)$ & $(n=21)$ & $(n=23)$ & $(n=19)$ & $(n=23)$ & $(n=34)$ & $(n=36)$ & $(n=12)$ & $(n=80)$ & $(n=6)$ \\
\hline
\end{tabular}

\begin{tabular}{|c|c|c|c|c|c|c|c|c|c|c|c|c|c|c|c|}
\hline & $(I I-24)$ & $(I I-20)$ & (III- & (III- & $(i \pi-4)$ & $(111-22)$ & (iit-21) & (III-20) & $(I I-1))_{1}$ & $(11-20)$ & (III- & $(11-30)$ & $(11-12)$ & $(n=00)$ & $(\pi i-0)$ \\
\hline \multicolumn{16}{|l|}{$\begin{array}{l}\text { Patient } \\
\text { characteristics }\end{array}$} \\
\hline Age, median (IQR) & $\begin{array}{l}32.9(28.6 \\
\text { to } 39.0)\end{array}$ & $\begin{array}{l}31.1(28.2 \\
\text { to } 35.8)\end{array}$ & $\begin{array}{l}35.5(25.8 \\
\text { to } 44.5)\end{array}$ & $\begin{array}{l}31.5(28.6 \\
\text { to } 45.9)\end{array}$ & $\begin{array}{l}33.7(28.5 \text { to } \\
38.0)\end{array}$ & $\begin{array}{l}30.5(26.6 \\
\text { to } 39.3)\end{array}$ & $\begin{array}{l}33.7(30.7 \\
\text { to } 38.0)\end{array}$ & $\begin{array}{l}35.5(28.6 \\
\text { to } 42.5)\end{array}$ & $\begin{array}{l}35.2(28.3 \\
\text { to } 44.5)\end{array}$ & $\begin{array}{c}30.6(25.5 \\
\text { to } 35.6)\end{array}$ & $\begin{array}{l}35.3(30.3 \\
\text { to } 45.9)\end{array}$ & $\begin{array}{c}32.9(26.3 \\
\text { to } 40.5)\end{array}$ & $\begin{array}{l}27.6(25.0 \\
\text { to } 33.1)\end{array}$ & $\begin{array}{l}32.5(28.4 \\
\text { to } 38.7)\end{array}$ & $\begin{array}{c}38.6(26.6 \\
\text { to } 44.5)\end{array}$ \\
\hline Female (\%) & $14(58.3)$ & 19 (67.9) & $22(64.7)$ & $10(66.7)$ & $32(65.3)$ & $13(59.1)$ & $13(61.9)$ & 16 (69.6) & $13(68.4)$ & $13(56.5)$ & $14(41.2)$ & $29(80.6)$ & $9(75.0)$ & $51(63.8)$ & $4(66.7)$ \\
\hline BMI, median (IQR) & $\begin{array}{l}21.2(20.1 \\
\text { to } 24.0)\end{array}$ & $\begin{array}{l}21.0(19.7 \\
\text { to } 27.4)\end{array}$ & $\begin{array}{l}21.9(18.7 \\
\text { to } 25.9)\end{array}$ & $\begin{array}{l}22.6(19.7 \\
\text { to } 27.6)\end{array}$ & $\begin{array}{l}21.2(19.3 \\
\text { to } 25.0)\end{array}$ & $\begin{array}{l}21.0(18.0 \\
\text { to } 22.3)\end{array}$ & $\begin{array}{l}22.0(20.7 \\
\text { to } 27.1)\end{array}$ & $\begin{array}{l}22.7(20.9 \\
\text { to } 27.6)\end{array}$ & $\begin{array}{l}20.1(17.7 \\
\text { to } 22.1)\end{array}$ & $\begin{array}{l}20.6(18.4 \\
\text { to } 24.3)\end{array}$ & $\begin{array}{l}21.3(20.6 \\
\text { to } 24.5)\end{array}$ & $\begin{array}{l}21.6(18.2 \\
\text { to } 27.1)\end{array}$ & $\begin{array}{l}19.8(17.8 \\
\text { to } 24.0)\end{array}$ & $\begin{array}{l}21.3(19.6 \\
\text { to } 26.0)\end{array}$ & $\begin{array}{l}18.9(17.0 \\
\text { to } 24.0)\end{array}$ \\
\hline $\begin{array}{l}\text { History of previous } \\
\text { TB (\%) }\end{array}$ & $4(16.7)$ & $8(28.6)$ & $5(14.7)$ & $6(40.0)$ & $7(14.3)$ & $4(18.2)$ & $5(23.8)$ & $4(17.4)$ & $2(10.5)$ & $6(26.1)$ & $7(20.6)$ & $8(22.2)$ & $1(8.3)$ & $16(20.0)$ & $1(16.7)$ \\
\hline \multicolumn{16}{|l|}{$\begin{array}{l}\text { WHO stage at } \\
\text { enrolment }\end{array}$} \\
\hline 1 or $2(\%)$ & $16(66.7)$ & $18(64.3)$ & $11(32.4)$ & $9(60.0)$ & $27(55.1)$ & $9(40.9)$ & $17(81.0)$ & $15(65.2)$ & $4(21.1)$ & $9(39.1)$ & $22(64.7)$ & $16(44.4)$ & $3(25.0)$ & $45(56.3)$ & 0 \\
\hline 3 or $4(\%)$ & $8(33.3)$ & $10(35.7)$ & $23(67.7)$ & $6(40.0)$ & $22(44.9)$ & $13(59.1)$ & $4(19.1)$ & $8(34.8)$ & $15(79.0)$ & $14(60.9)$ & $12(35.3)$ & $20(55.6)$ & $9(75.0)$ & $35(43.8)$ & $6(100)$ \\
\hline \multicolumn{16}{|l|}{ Blood Tests } \\
\hline $\begin{array}{l}\text { Hemoglobin } \\
\text { g/dL (IQR) }\end{array}$ & $\begin{array}{l}11.5(10.7 \\
\text { to } 13.7)\end{array}$ & $\begin{array}{l}10.5(8.5 \\
\text { to } 12.7)\end{array}$ & $\begin{array}{l}9.4(8.0 \\
\text { to } 11.0)\end{array}$ & $\begin{array}{l}11.5(10.6 \\
\text { to } 13.4)\end{array}$ & $\begin{array}{l}10.9(8.9 \\
\text { to } 12.0)\end{array}$ & $\begin{array}{l}8.8(8.0 \\
\text { to } 11.0)\end{array}$ & $\begin{array}{l}11.7(11.3 \\
\text { to } 14.1)\end{array}$ & $\begin{array}{l}11.1(8.8 \\
\text { to } 12.3)\end{array}$ & $\begin{array}{l}10.1(7.9 \\
\text { to } 11.6)\end{array}$ & $\begin{array}{l}9.0(7.9 \\
\text { to } 10.0)\end{array}$ & $\begin{array}{l}12.5(11.7 \\
\text { to } 13.9)\end{array}$ & $\begin{array}{l}9.5(8.8 \\
\text { to } 10.6)\end{array}$ & $\begin{array}{l}7.3(7.0 \\
\text { to } 7.6)\end{array}$ & $\begin{array}{l}10.9(8.8 \\
\text { to } 12.3)\end{array}$ & $\begin{array}{l}9.9(7.2 \\
\text { to } 10.1)\end{array}$ \\
\hline 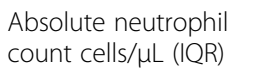 & $\begin{array}{l}3.3(2.5 \\
\text { to } 4.7)\end{array}$ & $\begin{array}{l}3.2(2.4 \\
\text { to } 4.3)\end{array}$ & $\begin{array}{l}4.0(2.5 \\
\text { to } 6.7)\end{array}$ & $\begin{array}{c}2.6(1.9 \text { to } \\
3.5)\end{array}$ & $\begin{array}{l}3.3(2.4 \\
\text { to } 5.3)\end{array}$ & $\begin{array}{l}4.7(3.0 \\
\text { to } 7.0)\end{array}$ & $\begin{array}{l}2.5(1.9 \\
\text { to } 3.3)\end{array}$ & $\begin{array}{l}3.2(2.5 \\
\text { to } 5.0)\end{array}$ & $\begin{array}{l}5.0(3.4 \\
\text { to } 6.7)\end{array}$ & $\begin{array}{l}4.3(2.6 \\
\text { to } 9.1)\end{array}$ & $\begin{array}{l}2.8(2.0 \\
\text { to } 3.5)\end{array}$ & $\begin{array}{l}3.6(2.8 \\
\text { to } 5.1)\end{array}$ & $\begin{array}{l}7.2(4.4 \\
\text { to } 9.4)\end{array}$ & $\begin{array}{l}3.3(2.4 \\
\text { to } 5.2)\end{array}$ & $\begin{array}{l}4.9(4.0 \\
\text { to } 6.2)\end{array}$ \\
\hline $\begin{array}{l}\text { Absolute lymphocyte } \\
\text { count, cells/uL (IQR) }\end{array}$ & $\begin{array}{l}1.9(1.6 \\
\text { to } 2.2)\end{array}$ & $\begin{array}{l}1.9(1.4 \\
\text { to } 2.7)\end{array}$ & $\begin{array}{l}0.8(0.6 \\
\text { to } 1.3)\end{array}$ & $\begin{array}{c}1.9(1.3 \text { to } \\
2.7)\end{array}$ & $\begin{array}{l}1.6(1.1 \\
\text { to } 2.0)\end{array}$ & $\begin{array}{l}1.1(0.7 \\
\text { to } 1.7)\end{array}$ & $\begin{array}{l}1.6(1.4 \\
\text { to } 2.7)\end{array}$ & $\begin{array}{l}1.7(1.0 \\
\text { to } 2.2)\end{array}$ & $\begin{array}{l}1.3(0.6 \\
\text { to } 1.7)\end{array}$ & $\begin{array}{l}1.4(0.7 \\
\text { to } 2.1)\end{array}$ & $\begin{array}{l}1.6(1.3 \\
\text { to } 2.3)\end{array}$ & $\begin{array}{l}1.5(0.9 \\
\text { to } 2.0)\end{array}$ & $\begin{array}{l}0.5(0.4 \\
\text { to } 1.2)\end{array}$ & $\begin{array}{l}1.6(1.1 \\
\text { to } 2.1)\end{array}$ & $\begin{array}{l}0.7(0.6 \\
\text { to } 0.7)\end{array}$ \\
\hline \multicolumn{16}{|l|}{$\begin{array}{l}\text { CD4 cell counts } \\
\text { (cells/ } / \mu \mathrm{l})\end{array}$} \\
\hline Median (IQR) & $\begin{array}{l}233(211 \\
\text { to } 275)\end{array}$ & $\begin{array}{l}143(124 \\
\text { to } 184)\end{array}$ & $\begin{array}{l}35(21 \\
\text { to } 68)\end{array}$ & $\begin{array}{l}158(44 \text { to } \\
189)\end{array}$ & $\begin{array}{l}137(68 \\
\text { to } 213)\end{array}$ & $\begin{array}{l}109(35 \\
\text { to } 184)\end{array}$ & $\begin{array}{l}188(138 \\
\text { to } 235)\end{array}$ & $\begin{array}{l}158(71 \\
\text { to } 205)\end{array}$ & $\begin{array}{l}52(21 \\
\text { to } 205)\end{array}$ & $\begin{array}{l}102(29 \\
\text { to } 140)\end{array}$ & $\begin{array}{l}189(114 \\
\text { to } 235)\end{array}$ & $\begin{array}{c}98 \text { (41 to } \\
194)\end{array}$ & $\begin{array}{l}28(16 \\
\text { to } 107)\end{array}$ & $\begin{array}{l}139(66 \text { to } \\
205)\end{array}$ & $\begin{array}{l}34(29 \\
\text { to } 62)\end{array}$ \\
\hline CD4 0 to 100 & - & - & $34(100)$ & $5(33.3)$ & 19 (38.8) & $10(45.5)$ & $3(14.3)$ & $8(34.8)$ & $12(63.2)$ & $11(47.8)$ & $8(23.5)$ & $18(50.0)$ & $8(66.7)$ & $29(36.3)$ & $5(83.3)$ \\
\hline CD4 101 to 200 & - & $28(100)$ & - & $7(46.7)$ & $13(26.5)$ & $8(36.4)$ & $8(38.1)$ & $8(34.8)$ & $1(5.3)$ & $11(47.8)$ & $11(32.4)$ & $9(25.0)$ & $4(33.3)$ & $27(33.8)$ & $1(16.7)$ \\
\hline CD4 >200 & $24(100)$ & - & - & $3(20.0)$ & $17(34.7)$ & $4(18.2)$ & $10(47.6)$ & $7(30.4)$ & $6(31.6)$ & $1(4.4)$ & $15(44.1)$ & $9(25.0)$ & 0 & $24(30.0)$ & 0 \\
\hline \multicolumn{16}{|l|}{$\begin{array}{l}\text { Log viral load } \\
\text { (copies/ml) }\end{array}$} \\
\hline Median (IQR) & $\begin{array}{l}4.7(4.2 \\
\text { to } 5.0)\end{array}$ & $\begin{array}{l}4.6(4.2 \\
\text { to } 5.3)\end{array}$ & $\begin{array}{l}5.1(4.7 \\
\text { to } 5.5)\end{array}$ & $\begin{array}{c}4.7 \text { ( } 4.2 \text { to } \\
5.0)\end{array}$ & $\begin{array}{l}4.8(4.4 \\
\text { to } 5.3)\end{array}$ & $\begin{array}{l}4.9(4.5 \\
\text { to } 5.4)\end{array}$ & $\begin{array}{l}4.7(4.4 \\
\text { to } 4.8)\end{array}$ & $\begin{array}{l}4.7(4.4 \\
\text { to } 5.2)\end{array}$ & $\begin{array}{l}4.9(4.5 \\
\text { to } 5.6)\end{array}$ & $\begin{array}{l}5.2(4.7 \\
\text { to } 5.6)\end{array}$ & $\begin{array}{l}4.4(3.9 \\
\text { to } 4.7)\end{array}$ & $\begin{array}{l}5.1(4.8 \\
\text { to } 5.4)\end{array}$ & $\begin{array}{l}5.6(5.1 \\
\text { to } 5.7)\end{array}$ & $\begin{array}{l}4.8(4.4 \\
\text { to } 5.3)\end{array}$ & $\begin{array}{l}5.5(4.9 \\
\text { to } 5.7)\end{array}$ \\
\hline
\end{tabular}




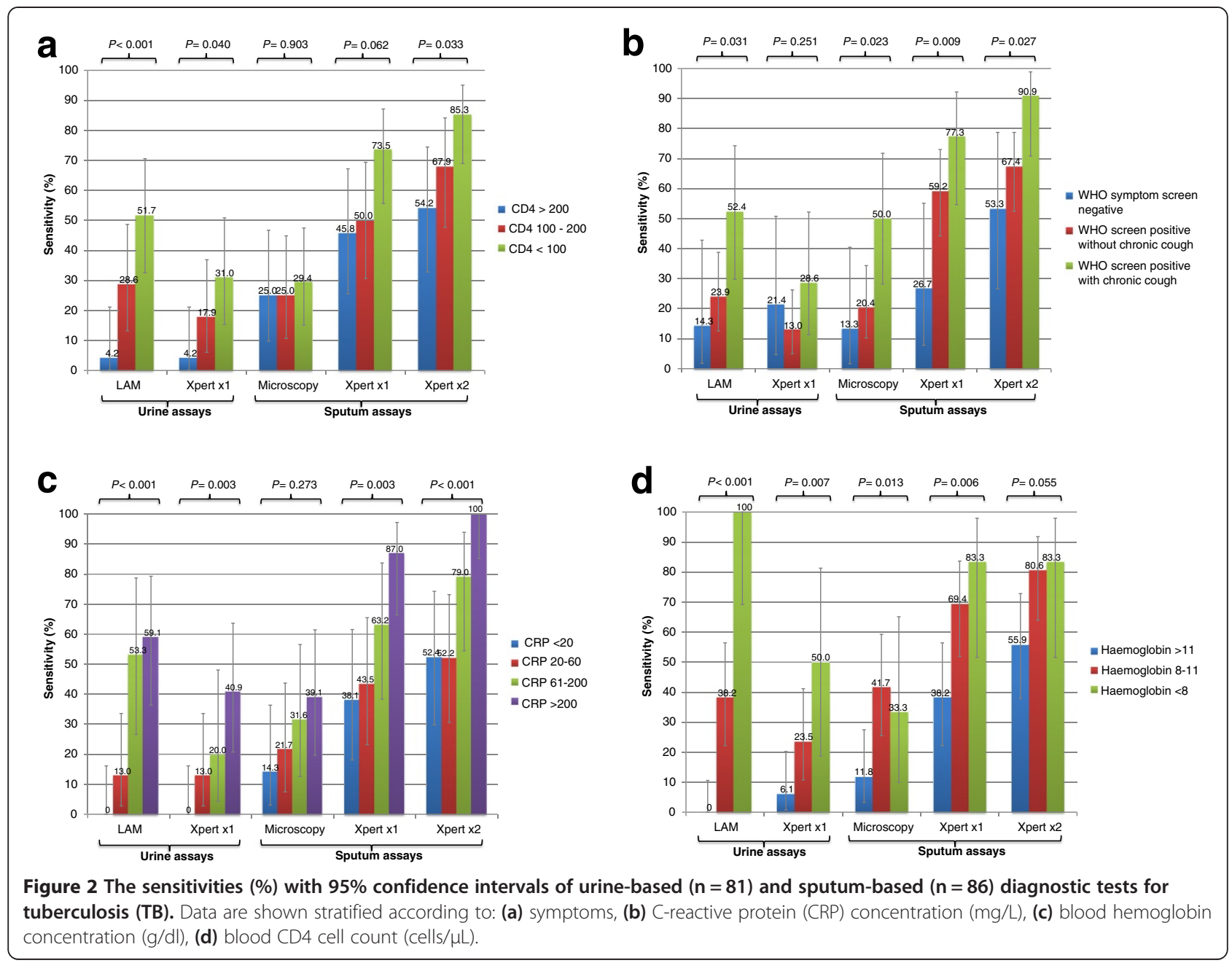

those with the CD4 cell counts $<100$ cells $/ \mu \mathrm{L}$, advanced symptoms, CRP concentrations $>200 \mathrm{mg} / \mathrm{L}$ or severe anemia $(<8.0 \mathrm{~g} / \mathrm{dL})$ and in those who subsequently died. These data indicate that screening sputum and/or urine and samples from patients using these new diagnostic approaches may enable rapid (same-day) diagnosis and treatment in more than $80 \%$ of those patients with the worst prognostic characteristics. Use of these approaches therefore has the potential to improve survival and these data provide the basis to justify large-scale intervention trials.

We chose to study four different indices of disease severity that reflected not only the degree of HIVassociated immunodeficiency (CD4 cell counts) but also other important aspects of the disease process. Patients with a negative WHO symptom screen [9] represent those with early 'sub-clinical' disease which tends to progress to symptomatic disease over time, presumably as mycobacterial load rises [23,24]. In contrast, those with chronic cough of two or more weeks' duration had more extensive pulmonary radiographic disease. C-reactive protein is an acute phase protein that reflects the systemic inflammatory response to infection and has prognostic value in patients with HIV-associated TB in this cohort [25]. Anemia is common in patients with HIV-associated TB, especially disseminated disease, and is an independent predictor of mortality in ART programs in sub-Saharan Africa [26-28].

The diagnostic sensitivity of Xpert MTB/RIF testing of sputum was strongly associated with greater disease severity across all prognostic indices. In the sickest patients with the lowest CD4 cell counts, highest CRP concentrations or severe anemia, the sensitivity of a single Xpert MTB/RIF test was more than twice that of smear microscopy. Although high sensitivity of Xpert MTB/RIF was found among those who subsequently died, failure of linkage of patients with the results of tests done in centralized National Health Laboratories Service laboratories and delays in patients returning to the clinic following recall clearly may have undermined any potential impact on survival $[29,30]$. This illustrates the huge need for rapid point-of-care diagnosis.

The observed higher sensitivity of Xpert MTB/RIF for sputum-based TB diagnosis among those with the lowest 


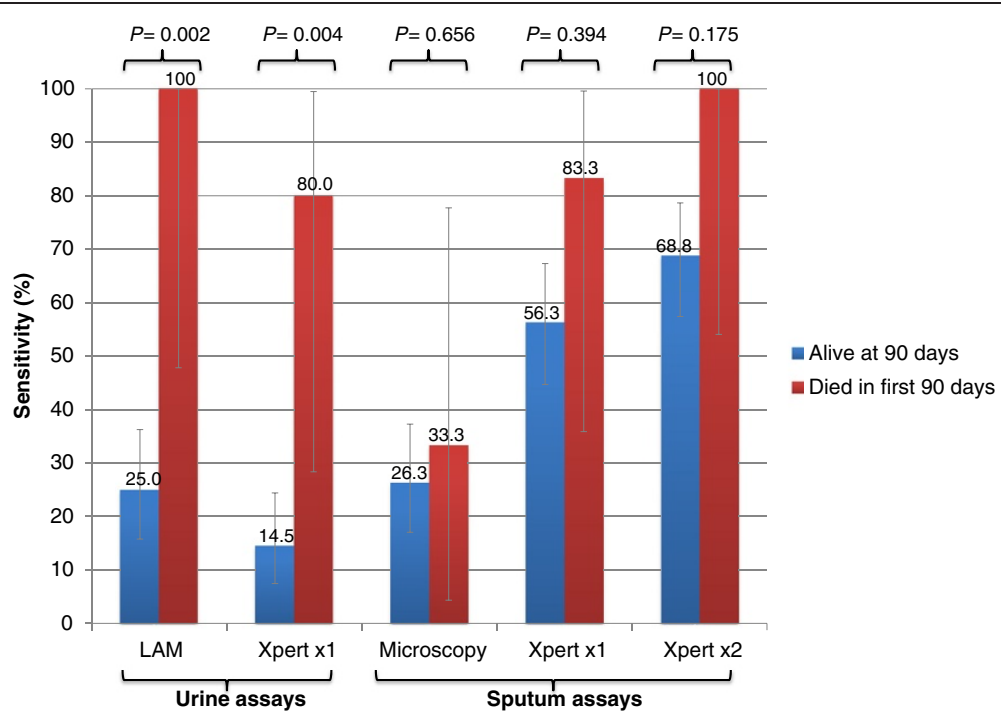

Figure 3 The sensitivities (\%) with $95 \%$ confidence intervals of urine-based $(n=81)$ and sputum-based $(n=86)$ diagnostic tests for tuberculosis (TB). Data are shown stratified according to vital status at 90 days.

CD4 cell counts appears to run contrary to the widely-held dogma that sputum mycobacterial load declines linearly with advancing immunodeficiency. However, the existing view-point is not well supported in the literature. We have recently reported on over 13,000 unselected cases of HIV-associated TB from Cape Town, South Africa [31]. Although the proportion of pulmonary cases testing sputum smear-positive initially declined in parallel with lower CD4 cell counts in the range 500 to 200 cells $/ \mu \mathrm{L}$, the overall relationship was non-linear with the proportion testing smear-positive increasing as CD4 counts declined further from 150 to zero cells $/ \mu \mathrm{L}$ [31]. The patterns observed in the present study are entirely consistent with this and suggest that at progressively lower CD4 cell counts below 150 cells $/ \mu \mathrm{L}$, the overall mycobacterial load rises substantially, facilitating microbiological diagnosis when using appropriate clinical samples and diagnostic tools.

Sputum samples were obtained by a dedicated study nurse with the assistance of nebulized hypertonic saline as described in detail elsewhere [32]. The quality of sputum samples is likely to be an important determinant of the yield of TB diagnoses from sputum-based diagnostics and is often much more difficult to obtain under routine program conditions and especially among very sick in-patient populations. A considerable advantage of urine-based TB diagnosis is the ease and rapidity of obtaining and handling
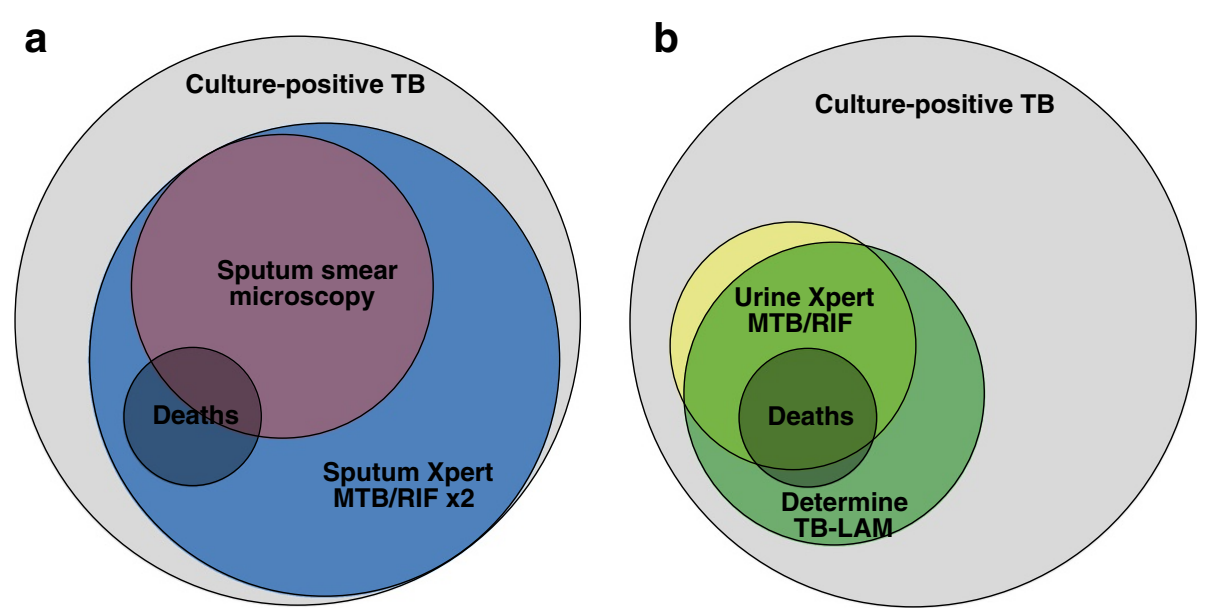

Figure 4 Venn diagrams showing total tuberculosis cases, deaths and the proportions diagnosed by different diagnostic assays. Data are shown for 81 cases with complete data using: (a) sputum-based investigation with smear microscopy or Xpert MTB/RIF testing of two sputum samples and (b) testing urine samples with either Determine TB-LAM or Xpert MTB/RIF. 
urine samples and fewer concerns about sample quality. Urine-based diagnosis, therefore, offers a very important alternative diagnostic approach [33].

Determine TB-LAM is a simple, low-cost lateral flow test that is able to diagnose TB within 30 minutes and provides a rapid means of screening for HIV-associated TB with moderate sensitivity and high specificity among those with the lowest CD4 cell counts [13,34]. This study extends our previous observations to show that although the overall sensitivity of Determine TB-LAM was low when screening unselected HIV-infected patients, useful sensitivity was observed among subsets of patients with poor prognostic features. Thus, the assay might best be used to screen in a targeted fashion HIV-infected patients with low CD4 counts and those with other poor prognostic characteristics such as moderate or severe anemia.

The association of the Determine TB-LAM assay sensitivity with blood hemoglobin concentration was particularly striking, detecting none of the TB cases who had a blood hemoglobin of $>11.0 \mathrm{~g} / \mathrm{dl}$ but detecting all cases with a hemoglobin of $<8 \mathrm{~g} / \mathrm{dl}$. It is likely that LAM antigenuria reflects disseminated mycobacteremia [35] and possible bone marrow involvement with TB. When retrospectively testing urine samples, Determine TB-LAM correctly diagnosed TB from a single clinical sample in all those who died during the three months follow-up. This assay offers the fastest means of screening for HIV-associated TB, permitting initiation of treatment in the sickest patients pending the results of further investigations.

The Xpert MTB/RIF assay may be used to test a wide range of non-respiratory samples [11]. When testing small volume $(2.0 \mathrm{ml})$ urine samples, the diagnostic sensitivity was not only greater among those with lower CD4 counts as previously reported [15], but was also higher among those with higher CRP concentrations, severe anemia and in those who later died. Xpert MTB/RIF detects DNA from whole Mycobacterium tuberculosis bacilli and so all patients with sputum culture-positive TB who also tested urine Xpert MTB/RIF-positive, therefore, had disseminated TB. Sensitivity is increased by concentrating larger volumes of urine by centrifugation [36] and this adds little to the laboratory processing time.

The finding of assay sensitivity varying substantially according to symptom status and disease severity may explain some of the heterogeneity between the results of studies assessing the diagnostic accuracy of tests for TB. This may well reflect differences between study populations. This might explain why, for example, the reported sensitivity of Xpert MTB/RIF for pulmonary TB was substantially lower during community-based active case finding compared to that observed during investigation of sick patients requiring hospital admission (62.6\% versus $86.1 \%$, respectively) $[37,38]$. Thus, studies of the accuracy of TB diagnostic assays should characterize symptom profiles and disease severity of participants.

Strengths of this study include the use of multiple indices of disease severity; the use of sputum induction to obtain high quality sputum samples; access to rigorous quality-assured microbiology laboratories with use of liquid culture as the diagnostic reference standard; the study of both sputum-based and urine-based diagnostic approaches and the ascertainment of vital status at 90 days. The cohort size and numbers of deaths, although limited, were nevertheless sufficient to address the study hypothesis. Weaknesses include the fact that this is a single study site; TB status was ascertained at one time-point and included only patients with sputum culture-positive disease; urine-based assays were done retrospectively and did not inform treatment decisions; and only small volumes of urine were available for Xpert MTB/RIF testing, potentially limiting the yield obtained by this means. We have simply reported on factors affecting diagnostic sensitivity as we have already reported on the specificities of these assays in this cohort which all exceed 98\% [13-15]. This study was observational and it cannot be deduced whether use of these new diagnostic approaches would be associated with improved survival.

\section{Conclusion}

In conclusion, sputum-based and urine-based TB diagnosis using Xpert MTB/RIF and Determine TB-LAM assays permit rapid diagnosis of HIV-associated TB among patients with advanced immunodeficiency and especially among those with poor prognostic characteristics. These data provide a strong rationale for largescale studies of the impact of the use of these assays on survival and on the operational and economic feasibility and sustainability of these approaches.

\section{Abbreviations}

ART: Antiretroviral treatment; CRP: C-reactive protein; LAM: Lipoarabinomannan; MGIT: Mycobacterial growth indicator tubes; MTB/RIF: Mycobacterium tuberculosis/resistance to rifampicin; TB: Tuberculosis.

\section{Competing interests}

The authors declare that they have no competing interests.

\section{Authors' contributions}

SDL initiated and planned the study. SDL, RW and MV collected the data. SDL and MV ran laboratory assays. ADK did the data analysis. SDL wrote the paper with input from RW and ADK. All authors approved the final version of the manuscript prior to submission.

\section{Acknowledgments}

SDL is funded by the Wellcome Trust. The funders had no role in study design, data collection and analysis, decision to publish, or preparation of the manuscript.

\section{Author details}

${ }^{1}$ The Desmond Tutu HIV Centre, Institute for Infectious Disease and Molecular Medicine, Faculty of Health Sciences, University of Cape Town, Cape Town, South Africa. ${ }^{2}$ Department of Clinical Research, Faculty of Infectious and Tropical Diseases, London School of Hygiene and Tropical 
Medicine, Keppel Street, London WC1E 7HT, UK. ${ }^{3}$ George Washington University School of Medicine and Health Sciences, Washington, DC, USA.

Received: 15 July 2013 Accepted: 17 September 2013 Published: 29 October 2013

\section{References}

1. World Health Organization: Global Tuberculosis Control Report 2012. Geneva: World Health Organization; 2012 [http://apps.who.int/iris/bitstream/10665/ 75938/1/9789241564502_eng.pdf]

2. Lucas SB, Hounnou A, Peacock C, Beaumel A, Djomand G, N'Gbichi JM, Yeboue $\mathrm{K}$, Honde M, Diomande M, Giordano C: The mortality and pathology of HIV infection in a west African city. AIDS 1993, 7:1569-1579.

3. Rana FS, Hawken MP, Mwachari C, Bhatt SM, Abdullah F, Ng'ang'a LW, Power C, Githui WA, Porter JD, Lucas SB: Autopsy study of HIV-1-positive and HIV-1-negative adult medical patients in Nairobi, Kenya. J Acquir Immune Defic Syndr 2000, 24:23-29.

4. Cohen T, Murray M, Wallengren K, Alvarez GG, Samuel EY, Wilson D: The prevalence and drug sensitivity of tuberculosis among patients dying in hospital in KwaZulu-Natal, South Africa: a postmortem study. PLoS Med 2010, 7:e1000296.

5. Wong EB, Omar T, Setlhako GJ, Osih R, Feldman C, Murdoch DM, Martinson NA, Bangsberg DR, Venter WD: Causes of death on antiretroviral therapy: a post-mortem study from South Africa. PLoS ONE 2012, 7:e47542.

6. Lawn SD, Harries AD, Meintjes G, Getahun H, Havlir DV, Wood R: Reducing deaths from tuberculosis in antiretroviral treatment programmes in sub-Saharan Africa. AIDS 2012, 26:2121-2133.

7. Lawn SD, Wood R: Tuberculosis in antiretroviral treatment services in resource-limited settings: addressing the challenges of screening and diagnosis. J Infect Dis 2011, 204:S1159-S1167.

8. Reid MJ, Shah NS: Approaches to tuberculosis screening and diagnosis in people with HIV in resource-limited settings. Lancet Infect Dis 2009, 9:173-184.

9. Getahun H, Kittikraisak W, Heilig CM, Corbett EL, Ayles H, Cain KP, Grant AD, Churchyard GJ, Kimerling M, Shah S, Lawn SD, Wood R, Maartens G, Granich R, Date AA, Varma JK: Development of a standardized screening rule for tuberculosis in people living with HIV in resource-constrained settings: individual participant data meta-analysis of observational studies. PLoS Med 2011, 8:e1000391.

10. Cain KP, McCarthy KD, Heilig CM, Monkongdee P, Tasaneeyapan T, Kanara N, Kimerling ME, Chheng P, Thai S, Sar B, Phanuphak P, Teeratakulpisarn N, Phanuphak N, Nguyen HD, Hoang TQ, Le HT, Varma JK: An algorithm for tuberculosis screening and diagnosis in people with HIV. N Engl I Med 2010, 362:707-716.

11. Lawn SD, Mwaba P, Bates M, Piatek A, Alexander H, Marais BJ, Cuevas LE, McHugh TD, Zijenah L, Kapata N, Abubakar I, McNerney R, Hoelscher M, Memish ZA, Migliori GB, Kim P, Maeurer M, Schito M, Zumla A: Advances in tuberculosis diagnostics: the Xpert MTB/RIF assay and future prospects for a point-of-care test. Lancet Infect Dis 2013, 13:349-361.

12. UNITAID Secretariat: Tuberculosis Diagnostic Technology Landscape 2012 Geneva: World Health Organization; 2012 [http://www.unitaid.eu/images/ marketdynamics/publications/UNITAID-Tuberculosis-Landscape_2012.pdf]

13. Lawn SD, Kerkhoff AD, Vogt M, Wood R: Diagnostic accuracy of a low-cost, urine antigen, point-of-care screening assay for HIV-associated pulmonary tuberculosis before antiretroviral therapy: a descriptive study. Lancet Infect Dis 2012, 12:201-209.

14. Lawn SD, Brooks SV, Kranzer K, Nicol MP, Whitelaw A, Vogt M, Bekker LG Wood R: Screening for HIV-associated tuberculosis and rifampicin resistance before antiretroviral therapy using the Xpert MTB/RIF assay: a prospective study. PLoS Med 2011, 8:e1001067.

15. Lawn SD, Kerkhoff AD, Vogt M, Wood R: High diagnostic yield of tuberculosis from screening urine samples from HIV-infected patients with advanced immunodeficiency using the Xpert MTB/RIF assay. J Acquir Immune Defic Syndr 2012, 60:289-294

16. Lawn SD, Myer L, Bekker LG, Wood R: Burden of tuberculosis in an antiretroviral treatment programme in sub-Saharan Africa: impact on treatment outcomes and implications for tuberculosis control. AIDS 2006, 20:1605-1612.

17. Lawn SD, Myer L, Orrell C, Bekker LG, Wood R: Early mortality among adults accessing a community-based antiretroviral service in South Africa: implications for programme design. AIDS 2005, 19:2141-2148.
18. Gupta A, Wood R, Kaplan R, Bekker LG, Lawn SD: Prevalent and incident tuberculosis are independent risk factors for mortality among patients accessing antiretroviral therapy in South Africa. PLOS ONE 2013, 8:e55824.

19. Gupta A, Wood R, Kaplan R, Bekker LG, Lawn SD: Tuberculosis incidence rates during 8 years of follow-up of an antiretroviral treatment cohort in South Africa: comparison with rates in the community. PLoS One 2012, 7:e34156.

20. Dawson R, Masuka P, Edwards DJ, Bateman ED, Bekker LG, Wood R, Lawn SD: Chest radiograph reading and recording system: evaluation for tuberculosis screening in patients with advanced HIV. Int J Tuberc Lung Dis 2010, 14:52-58.

21. Den Boon S, Bateman ED, Enarson DA, Borgdorff MW, Verver S, Lombard CJ, Irusen E, Beyers N, White NW: Development and evaluation of a new chest radiograph reading and recording system for epidemiological surveys of tuberculosis and lung disease. Int J Tuberc Lung Dis 2005, 9:1088-1096.

22. World Health Organization: Haemoglobin Concentrations for the Diagnosis of Anaemia and Assessment of Severity. Geneva: World Health Organization; 2011. (WHO/NMH/NHD/MNM/11.1). [http://www.who.int/vmnis/indicators/ haemoglobin.pdf]

23. Lawn SD, Kerkhoff AD, Wood R: Progression of subclinical culture-positive tuberculosis to symptomatic disease in HIV-infected individuals. AIDS 2011, 25:2190-2191.

24. Oni T, Burke R, Tsekela R, Bangani N, Seldon R, Gideon HP, Wood K, Wilkinson KA, Ottenhoff TH, Wilkinson RJ: High prevalence of subclinical tuberculosis in HIV-1-infected persons without advanced immunodeficiency: implications for TB screening. Thorax 2011, 66:669-673.

25. Lawn SD, Kerkhoff AD, Vogt M, Wood R: Diagnostic and prognostic value of serum C-reactive protein for screening for HIV-associated tuberculosis. Int J Tuberc Lung Dis 2013, 17:636.

26. Lawn SD, Harries AD, Anglaret X, Myer L, Wood R: Early mortality among adults accessing antiretroviral treatment programmes in sub-Saharan Africa. AIDS 2008, 22:1897-1908.

27. Maruza M, Albuquerque MF, Braga MC, Barbosa MT, Byington R, Coimbra I, Moura LV, Batista JD, Diniz GT, Miranda-Filho DB, Lacerda HR, Rodrigues LC, Ximenes RA: Survival of HIV-infected patients after starting tuberculosis treatment: a prospective cohort study. Int J Tuberc Lung Dis 2012, 16:618-624.

28. Lewis DK, Peters RP, Schijffelen MJ, Joaki GR, Walsh AL, Kublin JG, Kumwenda J, Kampondeni S, Molyneux ME, Zijlstra EE: Clinical indicators of mycobacteraemia in adults admitted to hospital in Blantyre, Malawi. Int J Tuberc Lung Dis 2002, 6:1067-1074.

29. Lawn SD, Kerkhoff AD, Wood R: Location of Xpert(R) MTB/RIF in centralised laboratories in South Africa undermines potential impact. Int J Tuberc Lung Dis 2012, 16:701.

30. Cohen G, Drain P, Noubary F, Cloete C, Nixon K, Parker G, Bassett I: Diagnostic Delays Associated with Xpert MTB/RIF Assay in a Centralized Laboratory for Pulmonary TB among HIV-positive Adults in South Africa. Atlanta, GA, USA: Program and abstracts of the 20th Conference on Retroviruses and Opportunistic Infections; 2013. Abstract \#846.

31. Gupta RK, Lawn SD, Bekker LG, Caldwell J, Kaplan R, Wood R: Impact of human immunodeficiency virus and CD4 count on tuberculosis diagnosis: analysis of city-wide data from Cape Town, South Africa. Int J Tuberc Lung Dis 2013, 17:1014-1022.

32. Lawn SD, Kerkhoff AD, Pahlana P, Vogt M, Wood R: Diagnostic yield of tuberculosis using sputum induction in HIV-positive patients before antiretroviral therapy [Short communication]. Int J Tuberc Lung Dis 2012, 16:1354

33. Peter J, Green C, Hoelscher M, Mwaba P, Zumla A, Dheda K: Urine for the diagnosis of tuberculosis: current approaches, clinical applicability, and new developments. Curr Opin Pulm Med 2010, 16:262-270.

34. Lawn SD: Point-of-care detection of lipoarabinomannan (LAM) in urine for diagnosis of HIV-associated tuberculosis: a state of the art review. BMC Infect Dis 2012, 12:103.

35. Shah M, Variava E, Holmes CB, Coppin A, Golub JE, McCallum J, Wong M, Luke B, Martin DJ, Chaisson RE, Dorman SE, Martinson NA: Diagnostic accuracy of a urine lipoarabinomannan test for tuberculosis in hospitalized patients in a High HIV prevalence setting. J Acquir Immune Defic Syndr 2009, 52:145-151.

36. Peter JG, Theron G, Muchinga TE, Govender U, Dheda K: The diagnostic accuracy of urine-based Xpert MTB/RIF in HIV-infected hospitalized patients who are smear-negative or sputum scarce. PLOS ONE 2012, 7:e39966. 
37. Dorman SE, Chihota VN, Lewis JJ, Shah M, Clark D, Grant AD, Churchyard GJ, Fielding KL: Performance characteristics of the Cepheid Xpert MTB/RIF test in a tuberculosis prevalence survey. PLoS ONE 2012, 7:e43307.

38. O'Grady J, Bates M, Chilukutu L, Mzyece J, Cheelo B, Chilufya M, Mukonda L, Mumba M, Tembo J, Chomba M, Kapata N, Maeurer M, Rachow A, Clowes P, Hoelscher M, Mwaba P, Zumla A: Evaluation of the Xpert MTB/RIF assay at a tertiary care referral hospital in a setting where tuberculosis and HIV infection are highly endemic. Clin Infect Dis 2012, 55:1171-1178. Erratum in: Clin Infect Dis 2013, 56:313.

doi:10.1186/1741-7015-11-231

Cite this article as: Lawn et al:. HIV-associated tuberculosis: relationship between disease severity and the sensitivity of new sputum-based and urine-based diagnostic assays. BMC Medicine 2013 11:231.

\section{Submit your next manuscript to BioMed Central and take full advantage of:}

- Convenient online submission

- Thorough peer review

- No space constraints or color figure charges

- Immediate publication on acceptance

- Inclusion in PubMed, CAS, Scopus and Google Scholar

- Research which is freely available for redistribution 